\title{
Design of Mechanical Hydraulic Jack
}

\author{
K.Sainath, MohdSalahuddin ${ }^{\mathrm{b}}$ MohdJibranBaig,MdAzam Ali Farooky, \\ Mohammed Siddique Ahmed,MohdRiyazUddin, Faraz Ur Rehman Azhar, Md \\ Shaffi. \\ ${ }^{a}$ Mechanical Engineering Department professor @ Sreyas Institute of Engineering \& Technology, Nagole, \\ Hyderabad-500068, \\ ${ }^{b}$ Student,Mechanical Engineering department, Sreyas Institute of Engineering \& TechnologyNagole, JNTUH, \\ Hyderabad-500068, INDIA. \\ ${ }^{c}$ Student, Mechanical Engineering, shadan college of Engineering \& technology \\ ${ }^{d}$ Mechanical Engineering student @ Nizam College Of Institute Of Engineering \& Technology. \\ e. Student at Technische Hochschule Ingolstadt Master in International automotive engineering, \\ f. Mechanical Engineering Diploma student @ R.I.T TurkalakhanapurMedak District Andhra Pradesh. \\ g. Student,Mechanical Engineering department, Sreyas Institute of Engineering \& TechnologyNagole, \\ Hyderabad-500068, INDIA. \\ h.Student,Mechanical Engineering department, Sreyas Institute of Engineering \& TechnologyNagole, \\ Hyderabad-500068, INDIA.
}

\begin{abstract}
A jack is a device that uses force to lift heavy loads. The primary mechanism with which force is applied varies, depending on the specific type of jack, but is typically a screw thread or a hydraulic cylinder. Jacks can be categorized based on the type of force they employ: mechanical or hydraulic. Mechanical jacks, such as car jacks and house jacks, lift heavy equipmentand are rated based on lifting capacity (for example, the number of tons they can lift). Hydraulic jacktend to be stronger and can lift heavier loads higher, and include bottle jacks and floor jacks. HYDRAULIC JACKSdepend on force generated by pressure. Essentially, if two cylinders (a large and a small one) are connected and force is applied to one cylinder, equal pressure is generated in both cylinders. However, because one cylinder has a larger area, the force the larger cylinder produces will be higher, although the pressure in the two cylinders will remain the same. Hydraulic jacks depend on this basic principle to lift heavy loads: they use pump plungers to move oil through two cylinders. The plunger is first drawn back, which opens the suction valve ball within and draws oil into the pump chamber. As the plunger is pushed forward, the oil moves through an external discharge check valve into the cylinder chamber, and the suction valve closes, which results in pressure building within the cylinder.
\end{abstract}

\section{THEORY}

HYDRAULICS:The word hydraulics is based on the Greek word for water, and originally covered the study of the physical behavior of water at rest and in motion. Use has broadened its meaning to include the behavior of all liquids, although it is primarily concerned with the motion of liquids. Hydraulics includes the manner in which liquids act in tanks and pipes, deals with their properties, and explores ways to take advantage of these properties.

Although the modern development of hydraulics is comparatively recent, the ancients were familiar with many hydraulic principles and their applications. The Egyptians and the ancient people of Persia, India, and China conveyed water along channels for irrigation and domestic purposes, using dams and sluice gates to control the flow. The ancient Cretans had an elaborate plumbing system. Archimedes studied the laws of floating and submerged bodies. The Romans constructed aqueducts to carry water to their cities. Torricelli, French physicist, EdmeMariotte, and later, Daniel Bernoulli conducted experiments to study the elements of force in the discharge of water through small openings in the sides of tanks and through short pipes. During the same period, Blasé Pascal, a French scientist, discovered the fundamental law for the science of hydraulics. Hydraulic jack is based on the Pascal's law whichstates that increase in pressure on the surface of a confined fluid is transmitted undiminished throughout the confined vessel or system.

Two common types of hydraulic jacks includeBOTTLE JACKS \& FLOOR JACKS..

\section{BOTTLE JACKS}

BOTTLE JACKS became popular in the early 1900s when the automobile industry began to take off. Also called hand jacks, bottle jacks provided an easy way for an individual to lift up a vehicle for roadside inspection or service. Their resemblance to milk bottles earned bottle jacks their name-today, they range in size and 
weight to offer a lifting capability ranging from one hundred to several tons. Bottle jacks feature a vertical shaft, which supports a platform (called a bearing pad) that directly bears the weight of the object as it is lifted.

Although they are most commonly used in the automobile industry (1.5 to 5 ton jacksare frequently used to lift cars), bottle jacks have other uses as well. In the medical industry they can be used in hydraulic stretchers and patient lifts. In industrial applications, they can be found as pipe benders used in plumbing, as cable slicers for electrical projects, and as material lifts within warehouses. Their ability to lift heavy loads plays a big role in enabling the repair of large agricultural machinery and in many construction operations. Bottle jacks can be secured within a frame, mounted on a beam, or simply used as they are for easier jack transportation.

\section{FLOOR JACKS}

Unlike bottle jack shafts, the shaft in a floor jacksis horizontal — the shaft pushes on a crank that connects to a lifting pad, which is then lifted horizontally. Floor jacks typically provide a greater range of vertical lift than bottle jacks, and are available in two sizes. The original jack is about four feet long, a foot wide, and weights around 200 pounds - they can lift 4-10 tons. A more compact model was later made, which is about three feet in length, and can lift 11/2 tons. Although mini jack are also produced, they are not a recognized standard type of floor jack. Typically, one of the first two sizes should be used.

\section{HYDRAULIC JACK}

It is a short stroke hydraulic lift which is fed from hand pump. The hydraulic jack may be portable. This is extensively used for lifting automobiles usually to facilitate and repair. And for replacing the punctured wheels. The hydraulic jack is perhapsone of the simplest forms of a fluid power system. By moving the handle of a small device, an individual can lift a load weighing several tons. A small initial force exerted on the handle is transmitted by a fluid to a much larger area.

The operation of hydraulic jack depends on "Pascal's law". This states that when a fluid is at rest in a closed vessel and if a certain pressure is applied at any point the pressure will be transmitted equally in all direction.

Mechanical advantage is obtained by a practical application of Pascal's law of transmission of fluid pressure. Two pistons of different sizes operate inside two cylinders suitably connected with a pipe so that pressure in each is the same. If " $p$ "is pressure and " $\mathrm{a}_{1}, \mathrm{a} 2$ " are the cross sectional area of cylinders, then a force "F" applied to the smaller plunger will make available a load "W" is lifted.

Where $\mathrm{p}=$ pressure of the fluid,

$\mathrm{a}_{1}=$ small cylinder area,

$\mathrm{a}_{2}=$ larger cylinder area,

$\mathrm{F}=$ force acting on smaller plunger,

$\mathrm{W}=$ load lifted.

If the volume of liquid is constant. The displacement of large piston will be proportionately to smaller plunger.

\section{WORKING OF HYDRAULIC JACK}

Hydraulic jack works on the principle of "Pascal's law".

When the handle is operated, the plunger reciprocates then the oil from the reservoir is sucked into the plunger cylinder during upward stroke of the plunger through the suction valve. The oil in the plunger cylinder is delivered into the ram cylinder during the downward stroke of the plunger through the delivery valve. This pressurized oil lifts the load up, which is placed on top plate of the ram. After the work is completed the pressure in the ram cylinder is released by unscrewing the lowering screw thus the pressure releases and the ram is lowered, then the oil is rushed into the reservoir.It consists of plunger cylinder on one side and ram cylinder on the other side. These two cylinders are mounted on base which is made of mild steel. Plunger cylinder consists of plunger which is used to build up the pressure by operating the handle. Plunger cylinder consists of two non-return valves i.e. one for suction and other for delivery. Ram cylinder consists of ram which lifts the load. The ram cylinder connected to delivery valve of plunger cylinder. It is also consists of lowering screw this is nothing but a hand operated valve used for releasing the pressure in the ram cylinder for get down the load.

VI.

SPECIFICATIONS OF HYDRAULIC JACK

- Rated capacity in tone

- Jack dimensions

- Lifting range in - $\mathrm{cm}$

- Oil capacity in - cc

- Net weight in - $\mathrm{kg}$ 


\section{CLASIFICATION OF HYDRAULIC JACK:}

- According to the source of power

- Manually operated jacks (hand or pedal operated)

- $\quad$ Power operated jacks (pump is used)

- According to the lift of ram

- High lift

- Medium lift

- Low lift

- According to the arrangement of cylinder

- Vertical
- Horizontal

- Inclined

- According to the number of cylinders

- Single cylinder

- Multi cylinder

- According to the construction

- Floor mounted jack

- Bottle jack

- Trolley jack

\section{DESIGN OF HYDRAULIC JACK \\ DESIGN CONSIDERATIONS\& METHODOLOGY:}

- $\operatorname{Load}(\mathrm{W})=06$ ton $(60 \mathrm{kN})$

- OPERATING PRESSURE (p) $=25 \mathrm{M} \mathrm{Pa}$

- Lift range $(\mathrm{L}) \quad=\quad 20 \mathrm{~cm}$

- Man effort put on the handle $(\mathrm{e}) \quad=20 \mathrm{Kg}$

- Permissible tensile stress of mild steel $\left(\sigma_{t}\right)=120 \mathrm{~N} / \mathrm{mm}^{2}$

- No. of strokes for lifting load (n) = 150

- Factor of safety $=5$

- Permissible shear stress of mild steel $(\tau)=20 \mathrm{~N} / \mathrm{mm}^{2}$

- Permissible compressive stress of mild steel $\left(\sigma_{c}\right)=\quad 20 \mathrm{~N} / \mathrm{mm}^{2}$

- Permissible compressive stress of cast iron $\left(\sigma_{\mathrm{CI}}\right)=120 \mathrm{~N} / \mathrm{mm}^{2}$

- Permissible shear stress of cast iron $\left(\tau_{\mathrm{CI}}\right)=35 \mathrm{~N} / \mathrm{mm}^{2}$

\section{DESIGN OF RAM CYLINDER}

It is a cylinder in which produces a slide way to the ram. The ram cylinder is made up of mild steel with density of 7.868 $\mathrm{gm} / \mathrm{cc}$. It is mounted on the base plate

Let,

$\begin{array}{llll}\mathrm{d} & = & \text { inner diameter of ram cylinder } & \\ \mathrm{D} & = & \text { outer diameter of ram cylinder } & \\ \mathrm{P} & = & \text { pressure acting on cylinder } & =25 \mathrm{Mpa} \\ \mathrm{W} & = & \text { load } & =60 \mathrm{kN} \\ \mathrm{T} & = & \text { thickness of ram cylinder } & \end{array}$

IX. DESIGN OF PLUNGER CYLINDER:

The plunger cylinder is made up of mild steel and is mounted on the base plate. It provides slide way to the plunger in order to build up the pressure.

Let

$\mathrm{d}_{\mathrm{p}}=$ inside dia of plunger cylinder

$$
=8 \mathrm{~mm}
$$

$\mathrm{D}_{\mathrm{p}}=$ outside dia of plunger cylinder

$t_{p}=$ thickness of plunger cylinder

Assume the thickness of plunger cylinder $\left(t_{p}\right)=5 \mathrm{~mm}$

Tensile strength of mild steel $\quad\left(\sigma_{\mathrm{t}}\right)=120 \mathrm{~N} / \mathrm{mm}^{2}$

By LAME’S equation

$$
\begin{gathered}
\mathrm{t}=5+5.0625(25-1) \\
126.5625-5.0625 \\
+5.0625=126.5625-25 \\
6.0625=101.5625 \\
=16.752 \mathrm{~N} / \mathrm{mm}^{2}
\end{gathered}
$$


Hence the induced tensile strength of M.S. is less than permissible value. So, the design is safe.

By using thickness and inside diameter, we can calculate the outer diameter of plunger cylinder

$$
\begin{aligned}
\mathrm{D}_{\mathrm{p}} & =d_{\mathrm{p}}+2 \mathrm{t} \\
& =8+2(5) \\
& =18 \mathrm{~mm} \\
& \text { Outer diameter of plunger cylinder }\left(\mathrm{D}_{\mathrm{P}}\right)=18 \mathrm{~mm}
\end{aligned}
$$

\section{DESIGN OF PLUNGER}

Let the plunger is made up of mild steel which reciprocates in plunger cylinder to increase the pressure of the oil.

Let,

$$
\begin{array}{lll}
\mathrm{W} & = & \text { load acting on plunger } \\
\mathrm{d}_{\mathrm{p}} & = & \text { diameter of plunger } \\
\mathrm{P} & = & \text { pressure developed in plunger cylinder }
\end{array}
$$

From standard table inside diameter of plunger cylinder is fixed i.e. $8 \mathrm{~mm}$

Load acting on plunger $=$ pressure $\times$ area

$=128.09 \mathrm{~kg}$

$$
=25 \times 10^{6}=1256.63 \mathrm{~N}
$$

We taken Load acting on the plunger $=130 \mathrm{~kg}$

XI.

\section{PLUNGER DISPLACEMENT}

We know that

$$
\begin{aligned}
& \text { Velocity ratio (V.R.) }= \\
& \begin{aligned}
\text { Assume V.R. }=150 \\
150==114.49 \mathrm{~mm} \\
=11.449 \mathrm{~cm}
\end{aligned}
\end{aligned}
$$

Therefore plunger displacement $=11.5 \mathrm{~cm}$

\section{DESIGN OF LEVER}

A lever is made up of mild steel and is used to apply load on the plunger. It is attached to the plunger with the help of pivot.

Assumptions,

1. Effort put on lever by man $=20 \mathrm{~kg}$

2. Load acting on plunger $\quad=130 \mathrm{~kg}$

Velocity ratio of lever $=6.5$

Required distance from fulcrum to load $=11.5 \mathrm{~cm}$

Total length of lever $=6.5 \times 11.5$

$$
=74.75 \mathrm{~cm} \text {. }
$$

We taken length of lever $=75 \mathrm{~cm}$

Lever is made up of mild steel.

Permissible tensile strength of mild steel $\left(\sigma_{t}\right)=120 \mathrm{~N} / \mathrm{mm}^{2}$

Where

$\mathrm{M}=$ maximum bending moment

$\mathrm{I}=$ moment of inertia

$=$ permissible tensile strength

$\mathrm{Y}=$ distance between outer most layer to neutral layer $\mathrm{Z}=$ section modulus 


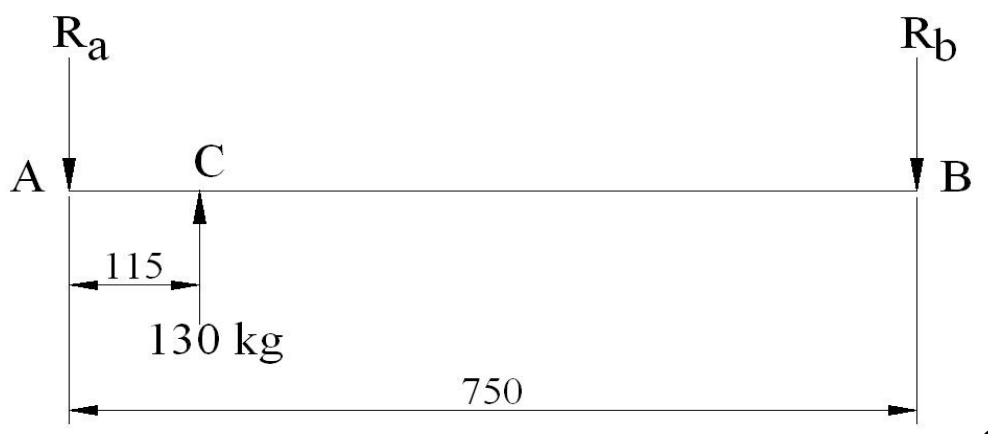

Calculation of bending moment:-

$\mathrm{R}_{\mathrm{a}}+\mathrm{R}_{\mathrm{b}}=130 \mathrm{~kg}$

$\mathrm{R}_{\mathrm{a}}+20=130$

$R_{\mathrm{a}}=130-20$

$\mathrm{R}_{\mathrm{a}}=110 \mathrm{~kg}$

Bending moment at $\mathrm{C}=0$

Bending moment at $\mathrm{B}=20 \times 9.81 \times 0.635=124.58 \mathrm{~N}-\mathrm{m}$

Bending moment at $\mathrm{A}=(20 \times 9.81 \times 0.75)-(130 \times 9.81 \times 11.5)=0$

From the above calculation

Maximum bending moment $=124.58 \mathrm{~N}-\mathrm{m}$

Where $\quad \mathrm{dl}=$ diameter of lever $=0.0219 \mathrm{~m}$

$=21.9 \mathrm{~mm}$

We adopt diameter of lever $=25 \mathrm{~mm}$

\section{DESIGN OF RESERVOIR}

The volume of oil circulated in the system is $835 \mathrm{c} . \mathrm{c}$

But, we take the volume of oil is $33 \%$ greater than the volume of circulated in the system.

Volume of oil in the reservoir $=835+\times 835$

$$
=1110 \mathrm{c} \cdot \mathrm{c}
$$

$$
[\times \mathrm{L}]-=1110 \text { c.c }
$$

Where

$$
\begin{aligned}
& \mathrm{D}=\text { outer dia of ram cylinder } \\
& \mathrm{L}=\text { height }=119.89 \mathrm{~mm}
\end{aligned}
$$

We adopt inner dia of reservoir ()$=$

Assuming thickness of reservoir ()$=$

$4 \mathrm{~mm}$

Therefore outer dia of reservoir $\left(D_{\mathrm{r}}\right)=$

$$
=\quad=\quad \begin{aligned}
& 122+(2 \times 4) \\
& 130 \mathrm{~mm}
\end{aligned}
$$

Fix the dimensions of base plate as

XIV.

DESIGN OF BASE

$1 \times b \times t_{b}=200 \times 150 \times 25$

$$
\begin{array}{ll}
\text { Where } & 1 \quad \text { = length of base } \\
\mathrm{b} & =\text { width of base } \\
t_{b} & =\text { thickness of base }
\end{array}
$$

Base is made up of mild steel.

Permissible compressive stress of M.S $\left(\sigma_{\mathrm{c}}\right)=20 \mathrm{~N} / \mathrm{mm}^{2}$

Compressive area of base $=200 \times 150$ 


$$
=30000
$$

Permissible shear stress of mild steel $(\tau)=20 \mathrm{~N} / \mathrm{mm}^{2}$

Shearing area $=\pi \times d \times t_{b}$

$$
=\pi \times 71.5 \times 25
$$

Where $\quad d=$ inner dia of ram cylinder

$t_{b}=$ thickness of base plate

Load acting on base $=100.17 \mathrm{KN}$

Checking for compressive strength

$\sigma_{\mathrm{c}}=3.339 \mathrm{~N} / \mathrm{mm}^{2}$

Checking for shear strength

$$
\tau=17.83 \mathrm{~N} / \mathrm{mm}^{2}
$$

The induced shear and compressive stresses are less than permissible valve. Hence the design is safe.

1. RAM CYLINDER:

\begin{tabular}{|l|l|l|l|l|}
\hline Sq.no. & Machine & Operation & Tools \& gauges & Time \\
\hline 05 & Lathe -1 & $\begin{array}{l}\text { Hold the job in the } \\
\text { chuck }\end{array}$ & & \\
\hline 10 & Face the end & Facing tool & \\
\hline 15 & -do- & Turn outer dia to Ø90 & Turning tool & \\
\hline 20 & -do- & Face the other end & Facing tool & \\
\hline 25 & -do- & Bore a hole of Ø72 & Boring tool & \\
\hline 30 & Boring machine & Bore a hole of Ø50 & Boring tool & \\
\hline 35 & -do- & Inspect & $\begin{array}{l}\text { Vernier and \&o \& go } \\
\text { gauges }\end{array}$ & \\
\hline 40 & & & \\
\hline
\end{tabular}

RAM:

\begin{tabular}{|l|l|l|l|l|}
\hline Sq.no. & Machine & Operation & Tools \& gauges & Time \\
\hline 05 & Universal testing machine & Check the raw material & & \\
\hline 10 & Lathe-1 & fix the job in the chuck & & \\
\hline 15 & - do- & Face the end & Facing tool & \\
\hline 20 & - do- & Turn $\varnothing$ 40 & Turning tool & \\
\hline 25 & -do- & Turn $\varnothing 20$ & Turning tool & \\
\hline 30 & - do- & Face the other end & Facing tool & \\
\hline 35 & -do- & Turn $\varnothing 72$ & Turning tool & \\
\hline 40 & - do- & Cut the grooves for 'o' ring & Form tool & \\
\hline 45 & Drilling machine & Drill 4 holes of $\varnothing 5$ on pcd $\varnothing 60$ & Drill bit & \\
\hline 50 & -do- & Ream the holes & Reamer & \\
\hline 55 & & Inspect & Vernier & \\
\hline
\end{tabular}

3. RAM TOP PLATE:

\begin{tabular}{|l|l|l|l|l|}
\hline Sq.no. & Machine & Operation & Tools\& gauges & Time \\
\hline 05 & & Check the raw material & Steel rule \&Vernier & \\
\hline 10 & Shaping machine & fix the job in the vice & & \\
\hline 15 & -do- & $\begin{array}{l}\text { Shpe the sides and faces of } \\
\text { plate }\end{array}$ & Shaping tool & \\
\hline 20 & Drilling machine & Drill a hole of Ø 22 & Drill bit & \\
\hline 25 & & $\begin{array}{l}\text { Surface plate } \\
\text { \&vernier }\end{array}$ & \\
\hline
\end{tabular}

\section{PLUNGER CYLINDER:}

\begin{tabular}{|l|l|l|l|l|}
\hline Sq.no. & Machine & Operation & Tools\& gauges & Time \\
\hline
\end{tabular}




\begin{tabular}{|l|l|l|l|l|}
\hline 05 & & Check the raw material & Vernier & \\
\hline 10 & Lathe-1 & fix the job in the chuck & & \\
\hline 15 & -do- & Face the end & Facing tool & \\
\hline 20 & -do- & Turn to $\varnothing 35 \& \varnothing 18$ & Turning tool & \\
\hline 25 & -do- & Face the other end & Facing tool & \\
\hline 30 & $\begin{array}{l}\text { Drilling } \\
\text { machine }\end{array}$ & $\begin{array}{l}\text { Drill a hole of } \varnothing 24.5 \& \\
\varnothing 7.5\end{array}$ & Drill bit & \\
\hline 35 & -do- & Ream to a dia of $\varnothing 25 \& \varnothing 8$ & Reamer & \\
\hline 40 & & Inspect & Vernier & \\
\hline
\end{tabular}

PLUNGER

\begin{tabular}{|l|l|l|l|l|}
\hline Sq.no. & Machine & Operation & Tools\& gauges & Time \\
\hline 05 & & Check the raw material & Steel rule \&Vernier & \\
\hline 10 & Lathe-1 & fix the job in the chuck & & \\
\hline 15 & -do- & Face the end & Facing tool & \\
\hline 20 & -do- & Turn $\varnothing 8$ & Turning tool & \\
\hline 25 & -do- & Face the other end & Facing tool & \\
\hline 30 & -do- & Turn $\varnothing 5$ & Turning tool & \\
\hline 35 & Diestock & Treading up to a length of 5 & Die & \\
\hline 40 & & Inspect & Vernier & \\
\hline
\end{tabular}

6. RESERVOIR:

\begin{tabular}{|l|l|l|l|l|}
\hline Sq.no. & Machine & Operation & Tools\& gauges & Time \\
\hline 05 & & Check the raw material & Vernier\& steel rule & \\
\hline 10 & Lathe-1 & fix the job in the chuck & & \\
\hline 15 & -do- & Face the end & Facing tool & \\
\hline 20 & -do- & Turn outer to $\varnothing 130$ & Turning tool & \\
\hline 25 & -do- & Face the other end & Facing tool & \\
\hline 30 & Boring machine & Bore a hole of $\varnothing 122$ & Boring tool & \\
\hline 35 & -do- & Bore a hole of $\varnothing 90$ & -do- & \\
\hline 40 & & Inspect & Vernier & \\
\hline
\end{tabular}

7. LEVER:

\begin{tabular}{|l|l|l|l|l|}
\hline Sq.no. & Machine & Operation & Tools\& gauges & Time \\
\hline 05 & & Check the raw material & Tape \&Vernier & \\
\hline 10 & Lathe-1 & fix the job in the chuck & & \\
\hline 15 & -do- & Face the end & Facing tool & \\
\hline 20 & -do- & Turn Ø 25 & Turning tool & \\
\hline 25 & -do- & Parting off bar & Parting tool & \\
\hline 30 & -do- & Face the other end & Facing tool & \\
\hline 35 & -do- & Knurling the bar at one end & Knurling tool & \\
\hline 40 & & Inspect & Vernier & \\
\hline
\end{tabular}

8. BASE PLATE:

\begin{tabular}{|l|l|l|l|l|}
\hline Sq.no. & Machine & Operation & Tools\& gauges & Time \\
\hline 05 & & Check the raw material & Steel rule \&Vernier & \\
\hline 10 & Shaping machine & fix the job in the vice & & \\
\hline 15 & -do- & shape the sides and faces & Shaping tool & \\
\hline 20 & Drilling machine & Fix the job in vice & & \\
\hline 25 & -do- & Drill a holes of $\varnothing 6$ & Expandable socket drill bit & \\
\hline 30 & -do- & Counter drill to $\varnothing 8$ & Drill bit & \\
\hline 35 & & Inspect & Vernier\& steel rule & \\
\hline
\end{tabular}




\section{ESTIMATING \& COSTING}

\section{- Ram cylinder:}

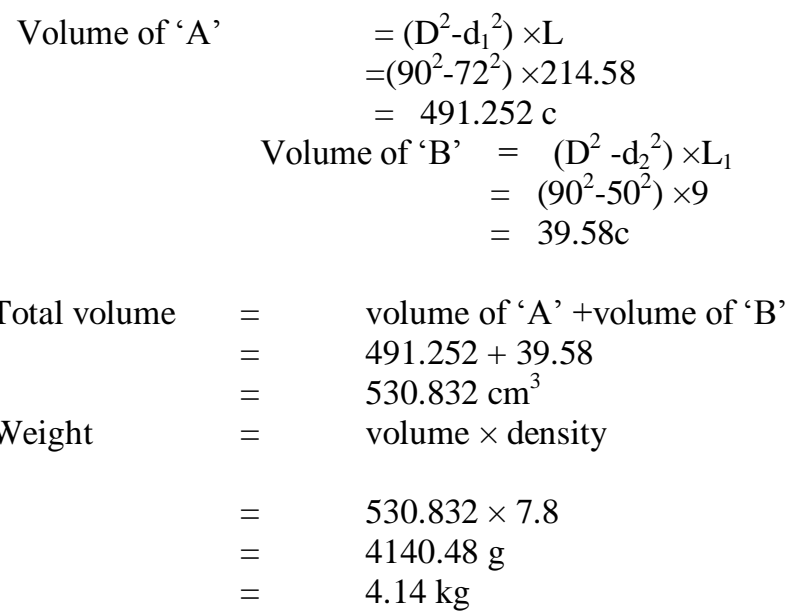

2. RAM:

$$
\begin{aligned}
& =\left(\mathrm{D}^{2}-\mathrm{d}_{2}^{2}\right) \times \mathrm{L}_{1} \\
& =\left(90^{2}-50^{2}\right) \times 9
\end{aligned}
$$

$$
\begin{array}{rll}
\text { Volume of 'A' } & & \\
& = & - \\
& = & 31.94 \mathrm{~cm}^{3}
\end{array}
$$

Volume of 'B' $=251.327 \mathrm{c}$

Volume of ' $\mathrm{C}$ ' $=3.1415 \mathrm{c}$

Total volume $=\quad$ volume of ' $\mathrm{A}$ ' + volume of ' $\mathrm{B}$ ' +volume of ' $\mathrm{C}$ '

\begin{tabular}{|c|c|c|}
\hline Weight & $=$ & volume $\times$ density \\
\hline & $=$ & $38.958 \times 7.8$ \\
\hline & $=$ & $306.52 \mathrm{~g}$ \\
\hline & $=$ & $0.306 \mathrm{~kg}$ \\
\hline
\end{tabular}

$$
\begin{array}{lll} 
& = & 31.94+251.327+3.1415 \\
\text { Weight }=\quad & \text { volume } \times \text { density } \\
& = & 286.40 \mathrm{~cm}^{3} \\
& = & 2062.40 \times 7.2 \\
& =2.062 \mathrm{~kg}
\end{array}
$$

\section{TOP PLATE:}

Volume $=$

$38.958 \mathrm{c}$

\section{PLUNGER CYLINDER:}

$$
\begin{aligned}
& \text { Volume of ' } A \text { ' = } \\
& =\times 10 \\
& =4.712 \mathrm{~cm}^{3} \\
& \text { Volume of ' } \mathrm{B} \text { ' }=2.735 \mathrm{~cm}^{3} \\
& \text { Volume of ' } \mathrm{C} \text { ' }=21.441 \mathrm{~cm} 3 \\
& \begin{array}{ll}
\text { Total volume } & \text { volume of 'A' }+ \text { volume of ' } \mathrm{B} \text { ' + volume of ' } \mathrm{C} \text { ' } \\
& =2.735+4.712+21.441+1.1309 \\
& =30.018 \mathrm{~cm}^{3} \\
& =\text { volume } \times \text { density } \\
& =30.018 \times 7.8
\end{array} \\
& =0.2341 \mathrm{~kg}
\end{aligned}
$$

\section{PLUNGER:}

$$
\begin{aligned}
\text { Volume of 'A' } & =0.502 \mathrm{~cm}^{3} \\
\text { Volume of ' } \mathrm{B} & =2.218 \mathrm{~cm}^{3} \\
\text { Total volume } & =\text { volume of 'A'+ volume of 'B' }
\end{aligned}
$$




$$
\begin{aligned}
& =0.5026+2.218 \\
& =2.7206 \mathrm{~cm}^{3}
\end{aligned}
$$

Weight $=$ volume $\times$ density

$$
\begin{aligned}
& =2.7206 \times 7.8 \\
& =0.212 \mathrm{~kg}
\end{aligned}
$$

6. LEVER:

$$
\begin{aligned}
& \text { Volume }=368.155 \mathrm{~cm}^{3} \\
& \text { Weight }=\quad \text { volume } \times \text { density } \\
& =\quad 368.155 \times 7.8 \\
& =\quad 2.87 \mathrm{~kg}
\end{aligned}
$$

\section{RESERVOIR:}

Volume of ' $A$ ' $=329.339 \mathrm{~cm}^{3}$

Volume of ' $\mathrm{B}$ ' $=27.64 \mathrm{~cm}^{3}$

Total volume $=$ volume of ' $\mathrm{A}$ ' + volume of ' $\mathrm{B}$ '

$$
=329.339+27.64
$$

Weight = $\quad \begin{array}{ll}356.979 \mathrm{~cm}^{3} \\ \text { volume } \times \text { density }\end{array}$

$$
\begin{array}{ll}
= & 356.339 \times 7.8 \\
=\quad & 2.78 \mathrm{~kg}
\end{array}
$$

\section{BASE PLATE:}

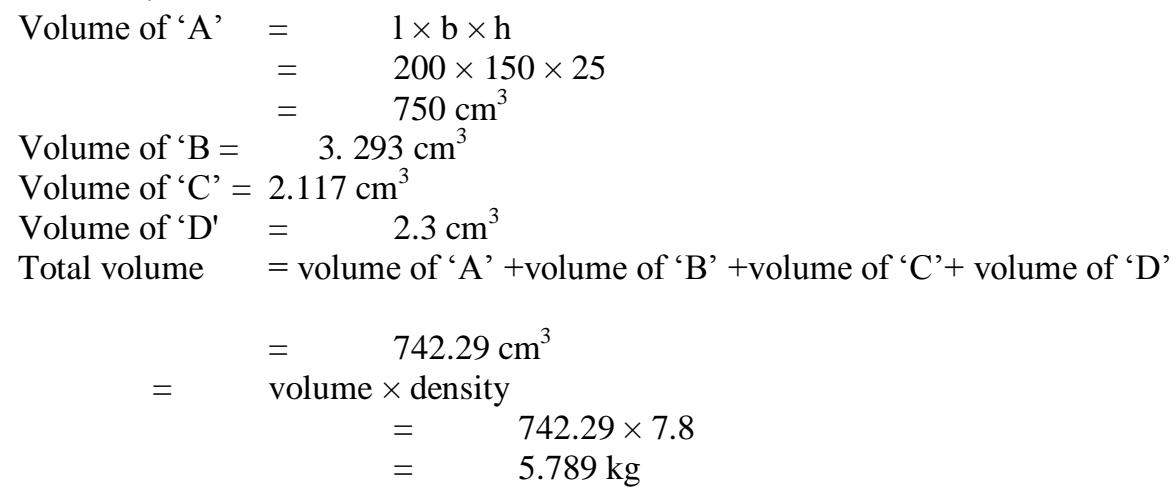

Net weight of the unit $=4.14+2.062+0.306+0.2341+0.212+2.87+2.78$ $+5.789$

$$
=18.39 \mathrm{~kg}
$$

\begin{tabular}{|c|l|l|l|l|}
\hline S.NO & DESCRIPTION & $\begin{array}{l}\text { MATERIAL } \\
\text { WEIGT / kg }\end{array}$ & COST /kg WEIGHT in Rs & TOTAL COST IN Rs \\
\hline 1. & Mild steel & 16.328 & 26 & 424.528 \\
2. & Cast iron & 2.062 & 24 & 49.488 \\
\hline \multicolumn{4}{|r|}{ Total direct material cost } & 474.016 \\
\hline
\end{tabular}

$\%$ of scrap $=15 \%$ is added to direct material cost

Total direct material cost $=$ Rs. 550

\section{- Breakeven point}

\section{BREAKEVEN ANALYSIS}

\section{Breakeven quantity (B.E.Q) =}

Where $\quad F=$ fixed cost

$$
\begin{aligned}
& \mathrm{SP}=\text { selling price per unit }=\text { Rs } 1700 \\
& \mathrm{~V}=\text { variable cost per unit } \\
& = \\
& =\text { Rs } 1005.33 \\
& \quad \text { B.E.Q }=
\end{aligned}
$$


2. Breakeven value $=$ Rs $3,06,316.6$

$$
=180.18=181
$$

3. Breakeven sales (or) $\%$ of breakeven quantity $=0.4641,=46.41 \%$

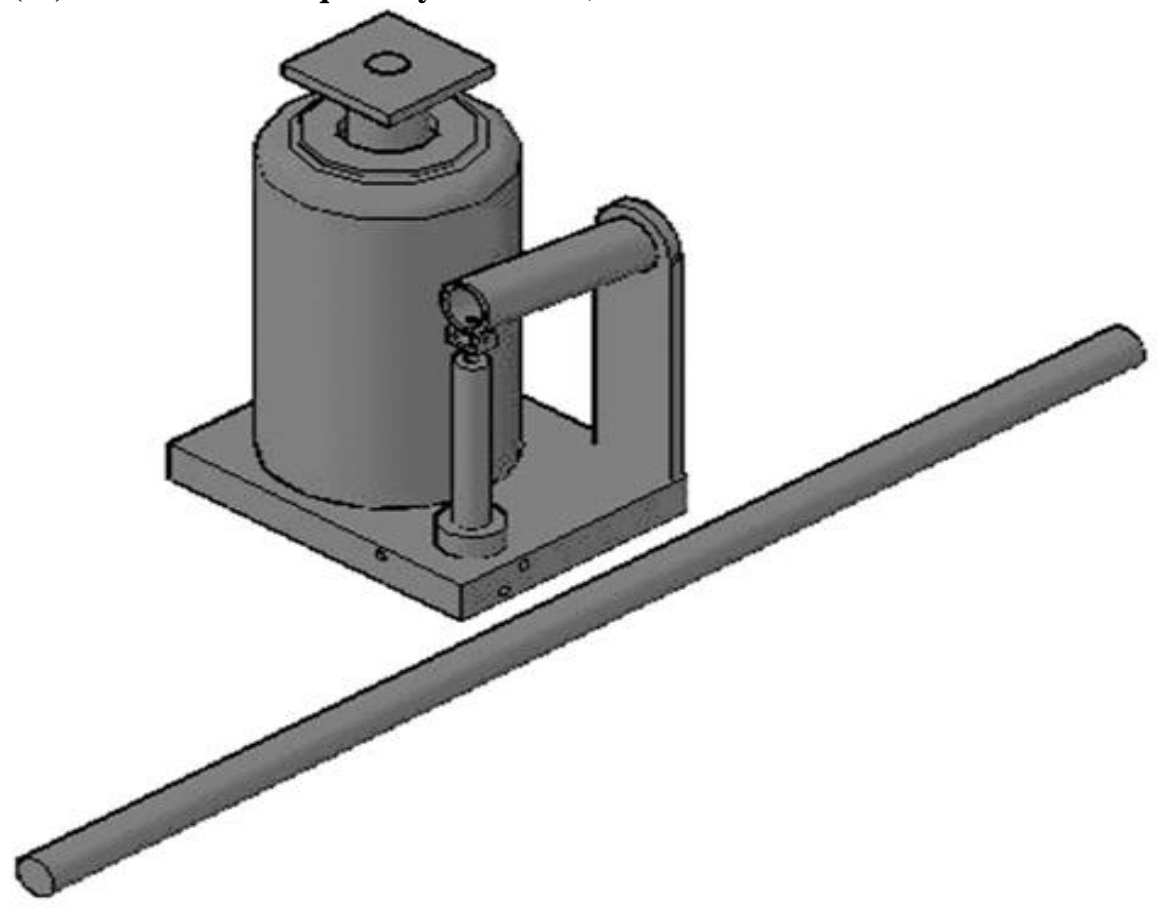

HYDRAU LIC JACK 


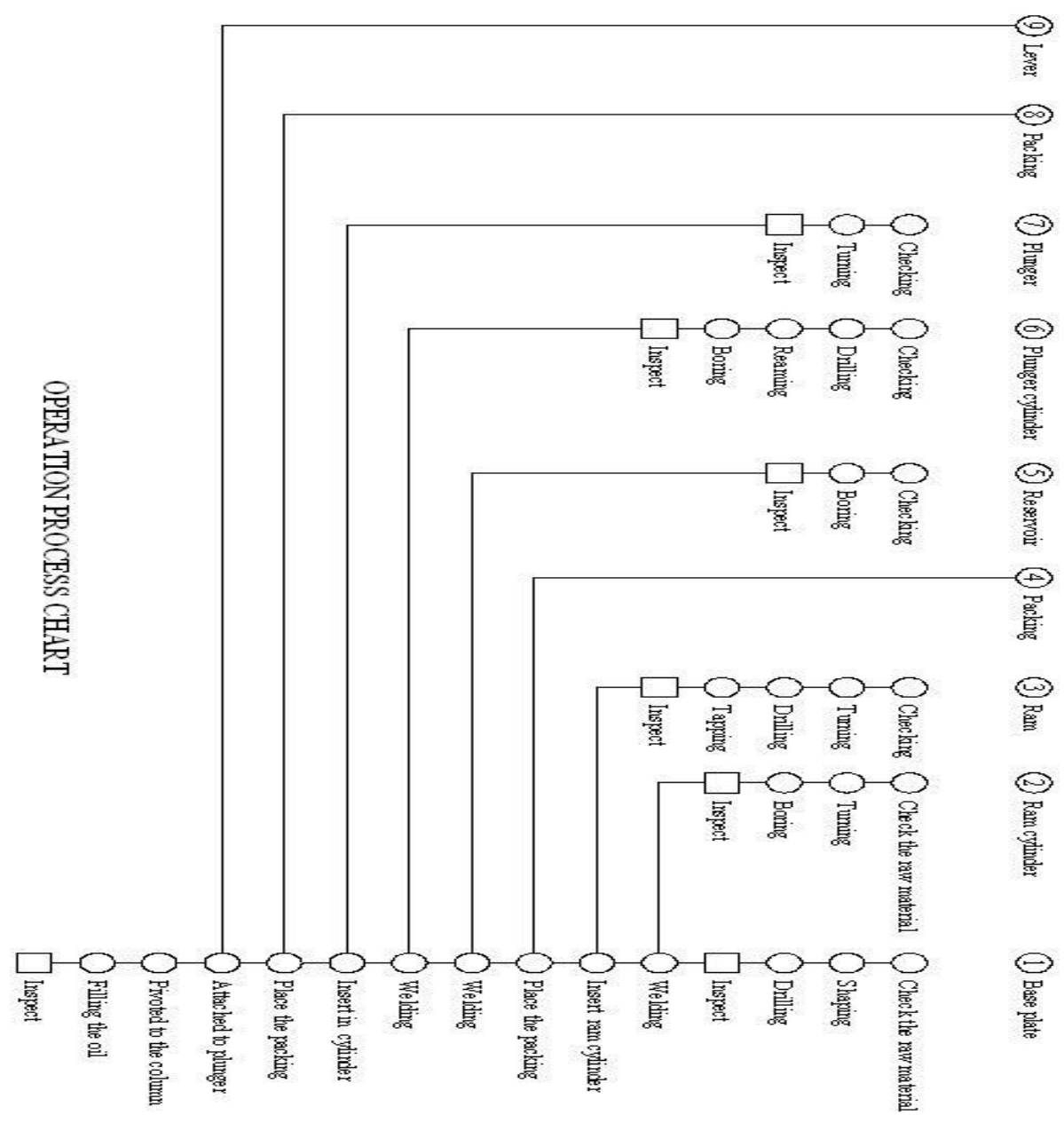

ORGANISATION STRUCTURE

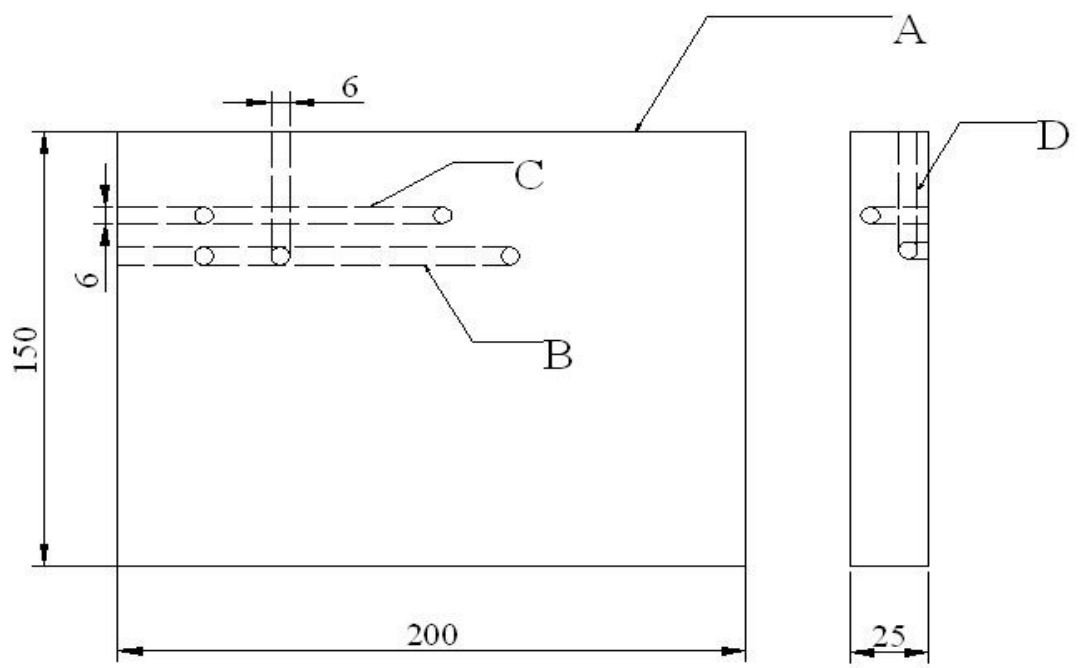

BASE PLATE 

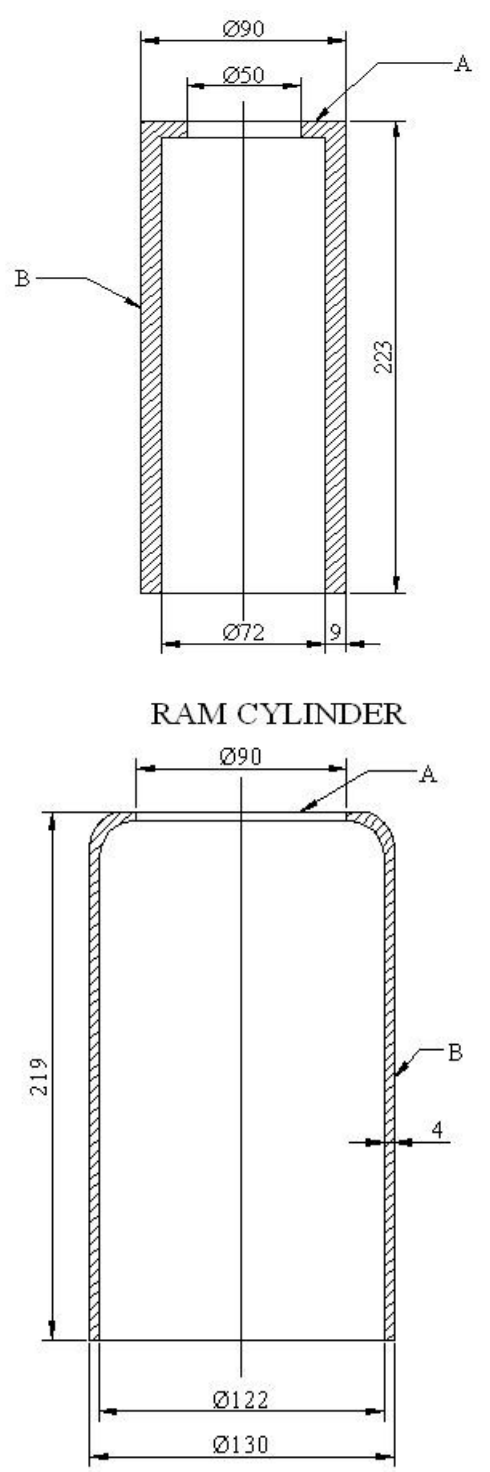

RESERVOIR

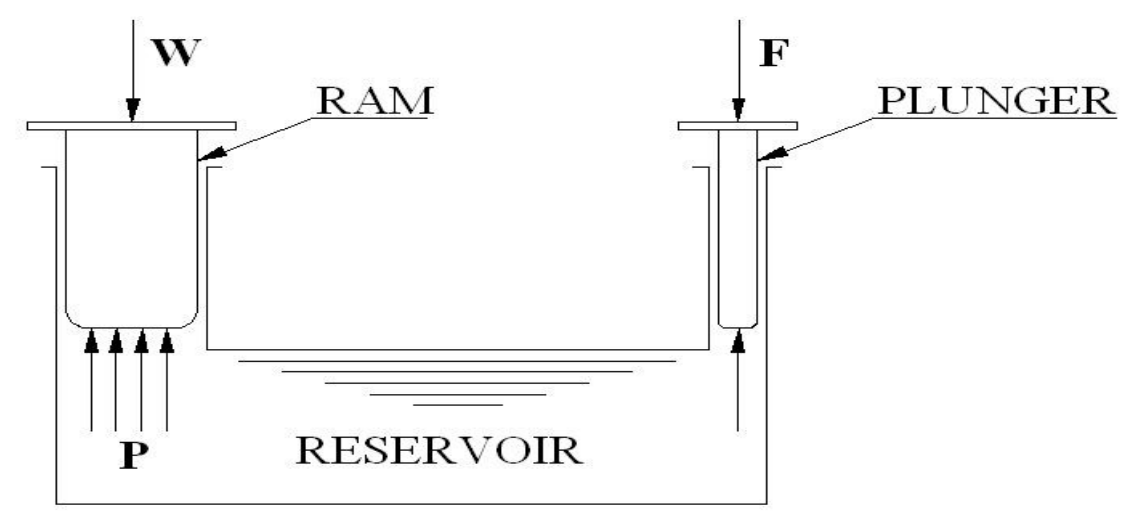

PRINCIPLE OF HY DRAULIC JACK 

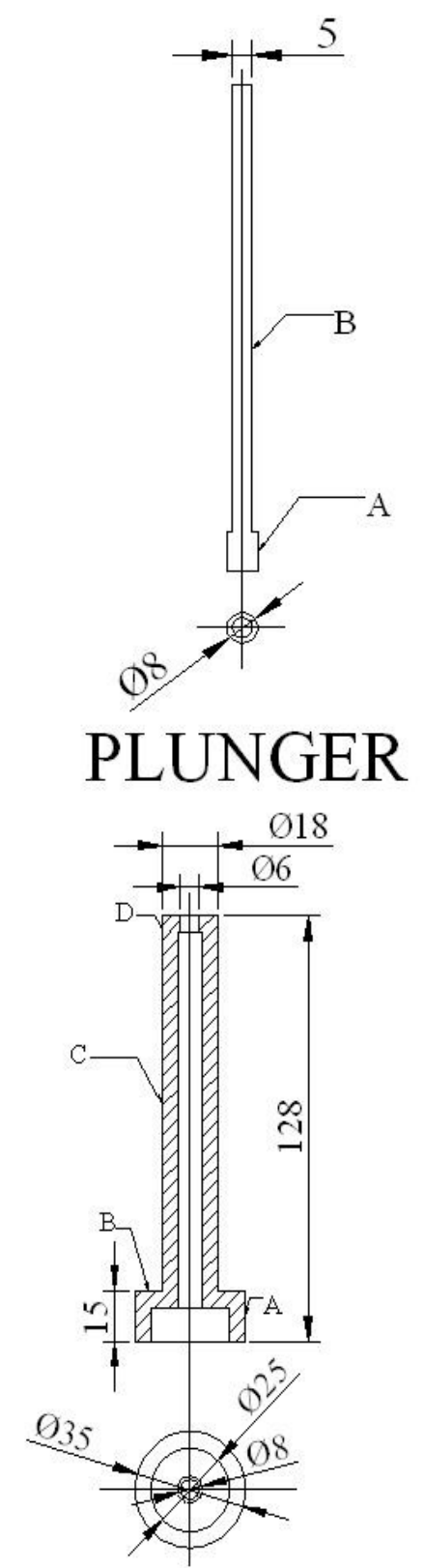

PLUNGER CYLINDER

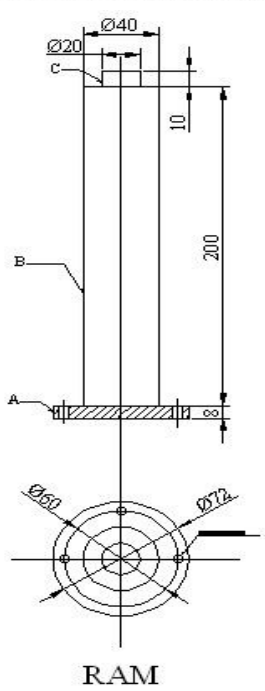




\section{REFERENCES}

[1] Electric Scissor Jacks, Jackmaster. "Electric Scissor Jacks". Retrieved 8 February 2014.

[2] William Cox (July 2001), "Light Talk On Heavy Jacks", Old-House Journal: 37

[3] Brian S. Elliott (2006), "Air-Over-Hydraulic Jacks", Compressed Air Operations Manual, McgrawHill Professional, Pp. 56-58, Isbn 978-0-07-147526-6

[4] George William Sutcliffe (1895), Steam Power And Mill Work Principles And Modern Practice, Whittaker \& Co., P. 828, "The Bottle-Jack Is Exceedingly Firm And Safe For Short Vertical Lifts, But Is Not Convenient For Pushing In A Horizontal Or Oblique Direction."

[5] John Norman (2009), Fire Department Special Operations, Fire Engineering Books, P. 51, Isbn 978-1-59370-193-2

[6] Reference Books:

[7] Strength Of Materials - A.S.Ramamrutham

[8] Applied Mechanics - R.S.Khurmi

[9] Applied Mechanics And Strength Of Materials - Dr. R.K.Bansal

[10] Applied Mechanics And Strength Of Materials - I.B.Prasad

[11] Pneumatics \& Hydraulics - Harry. L. Stewart

[12] Introduction To Pneumatics - Festo Manual

[13] Fundamentals Of Pneumatic Control Engineering - Festo Manual

[14] Hydraulic Machines, Jagadishlal, , Metropolitan Book Co. Pvt. Ltd., 1, Faiz Bazaar, New Delhi 110006.

[15] Hydraulics,Andrew Parr (A Technician's And Engineer's Guide) Fundamentals Of Pneumatic Control Engineering -Festo Manual

[16] Fluid Mechanics And Hydraulic Machines,R. K. Bansal, Laxmi Publications Pvt.,Ltd,22,Golden House, Daryaganj, New Delhi - 110002

[17] Jagadishlal, Hydraulic Machines, 1990, Published By Metropolitan Book Co. Pvt. Ltd., 1 Faiz Bazaar, New Delhi - 6 .

[18] R.K.Bansal, Fluid Mechanics And Hydraulic Machines , Edn. 8, Laxmi Publications P. Ltd., 22 Golden House, Daryaganj, New Delhi 110002 - 2003.

[19] Andrew Parr, Hydraulics And Pneumatics (A Technician's And Engineer's Guide) Festo Manual, Fundamentals Of Pneumatic Control Engineering

[20] Text Book Of Hydraulics By H. Meixner And R.Kober, Edn. 1990 Published By Fiesto Didactic Kg, D - 7300 Esslingen, 1977, 1988.

[21] A Text Book Of Hydraulics, Fluid Mechanics And Hydraulic Machines, R.S. Khurmi, - Edn.18, S.Chand \& Co., Ram Nagar, New Delhi - 110 055, Ram Nagar, New Delhi - 2002

[22] A Text Book Of Fluid Mechanics And Hydraulic Machines - By, R. K Rajput And S. Chand \& Co,Ram Nagar, New Delhi - 110055.

[23] Jack LewinDesign Of Hydraulic Gates By Jack Lewin

[24] Thomas Telford, 1995 - Hydraulic Engineering - Hydraulics Of Spillways And Energy Dissipators Rajnikant M. Khatsuria. 